\title{
Exterior and constitutional features of first-calf cows of black-and-white cattle of different genotypes
}

\author{
Orest Basonov ${ }^{1, *}$, Dmitry Petrov ${ }^{1}$, Amanbai Karynbaev ${ }^{2,3}$, Zaurbek Aisanov ${ }^{4}$, and Tsrai \\ Kagermazov $^{4}$ \\ ${ }^{1}$ FSBEI HE Nizhny Novgorod State Agricultural Academy, 97, Gagarin Avenue, 603107 Nizhny \\ Novgorod, Russia \\ ${ }^{2}$ Non-commercial JSC "National Agrarian Science and Educational Centre", 4A, Kurgaldzhinskoe \\ shosse, 010000 Nur-Sultan, Republic of Kazakhstan \\ ${ }^{3}$ FSBEI HE Southern Federal University, 105/42 Bolshaya Sadovaya Str., 344006 Rostov-on-Don, \\ Russia \\ ${ }^{4}$ Kabardino-Balkarian State Agricultural University named after V.M. Kokov, Lenin Avenue, 1V, \\ 360030 Nalchik, Russia
}

\begin{abstract}
The dairy cattle breeding development depends largely on the culture of raising young animals of the cattle. Production and maintaining healthy young animals is an extremely challenging task for livestock breeders $[1,3,12,14]$. Breeding of dairy replacement heifers is considered a major element of the breeding system and milk production technology, since the formation of milk production takes place just in the process of growth and development. Individual selection of parental pairs affects not only the cattle reproductive ability, but also the growth of offspring $[2$, 4,13], [5-11].
\end{abstract}

\section{Introduction}

The dairy cattle breeding development depends largely on the culture of raising young animals of the cattle. It is very difficult to produce and maintain healthy young animals. Correct dairy young-stock breeding is the reason for the optimal expression of genetically coded productive capabilities of animals in the first stage of their growth and development. The peculiarities of the growth and development of the animal, determined by heredity and environmental conditions, especially feeding are taken into account when organizing breeding and feeding.

This article provides a comparative analysis of the dynamics of live weight, body measurements and body build indices of first-calf cattle of several combinations of selection. First-calf heifers of the fifth experimental group, produced by fathers and mothers with the cross line affinity, exceeded in live weight and gain of animals included in the control group, whose parents had pure lines.

\footnotetext{
*Corresponding author: dekanat.zootexnia@yandex.ru
} 
Under the same conditions of keeping and feeding, the heifers of the studied groups grew in a different way, and in the process of ontogenesis were revealed several differences in the indices. The first-calf heifers of the 5th group in different age periods had the highest live weight and exceeded the peers of the $1 \mathrm{st}$, 3rd and 4th groups from 10 to $23 \mathrm{~kg}$ with a significant difference. The highest average daily gain up to 6 months of age were observed in the animals of the 5th experimental group. For the whole growing period (18 months), the animals in the control group had the highest absolute gain, which was significantly higher than that in the experimental groups.

The body build indices as leggy, stretchiness, pelvis-chest, chest, blockiness and boniness were calculated, as well as the coefficient of milk production, which was used to judge the direction of the animal productivity. First-calf cattle belongs to the dairy-meat direction of productivity according to the leggy and stretchiness index. All groups belong to the milk production direction according to the downwardness and chest index, and to the meat one according to the boniness index.

Study purpose and objectives. The purpose of our study was to determine the growth and development of first-calf heifers depending on the breeding pairs combinations.

\section{Materials and Methods}

Scientific and economic study was carried out at Plemzavod im. Lenin LLC in the Koverninsky district of the Nizhny Novgorod region. The animals were divided into groups depending on the combinations of selection with subsequent biometric processing of the primary research material. Five groups of black-and-white first-calf heifers were formed. The first control group consisted of animals produced from pure lines with both the paternal and maternal ancestors of the same line $(n=30)$. The second group consisted of cows with the paternal ancestors of one line, and the maternal ancestors of another line $(n=8)$. The third group consisted of first-calf heifers with the paternal ancestors of the same pure line, and the maternal ancestors with the cross line affinity $(n=14)$. The fourth group consisted of first-calf heifers with the paternal ancestors with the cross line affinity, and the maternal ancestors of the same pure line $(n=20)$. The fifth group consisted of animals with paternal and maternal ancestors with the cross line affinity $(n=27)$.

\section{Results and Discussion}

The growth and development of an animal organism at different stages of life does not proceed equally quickly. The major factor affecting the growth and development of young animals is feeding. The correct development of a young animal related to the provision with fresh air, light and warmth. Well-organized loose housing creates especially favorable conditions for the development of young cattle. Growth and development are studied according to the individual weighing data from the moment of birth to 18 months of age (Table 1).

It was identified that under the same conditions of feeding and keeping, the animals of the studied groups grew in a different way, and in the process of ontogenesis, several differences in indicators were revealed. The first-calf heifers of the 5th group have the highest live weight at the age of 6 months related to the 3rd and 4th group. The difference is $14 \mathrm{~kg}$ with $\mathrm{P}>0.999$ and $8 \mathrm{~kg}$ with $\mathrm{P}>0.99$, as well as the control group prevails over the peers of the $3 \mathrm{rd}$ group, $7 \mathrm{~kg}$ with a significant difference $\mathrm{P}>0.95$. The first-calf heifers of the 5th experimental group at 10 months of age are leading in terms of live weight related to the groups 1,3 and $4-10,23 \mathrm{~kg}(\mathrm{P}>0.99)$ and $17 \mathrm{~kg}$ with $\mathrm{P}>0.999$. 
The control group animals are superior at the age of 12 months over their peers of the 3rd and 4th groups by 19 and $10 \mathrm{~kg}$ with a significant difference $\mathrm{P}>0.95$, as well as the first-calf heifers of the 5th experimental group - 26 and $17 \mathrm{~kg}(\mathrm{P}>0.99)$. The cattle of the 5 th group are distinguished by a high live weight at the age of 18 months related to the 2nd and 3rd group, the difference is $31 \mathrm{~kg}$ and $21 \mathrm{~kg}$ with $\mathrm{P}>0.99$, as well as animals of the 4th group - $25 \mathrm{~kg}(\mathrm{P}>0.99)$ and $15 \mathrm{~kg}(\mathrm{P}>0.95)$. The first-calf heifers of the control group prevail over the peers of the 2 nd experimental group by $20 \mathrm{~kg}$ with $\mathrm{P}>0.95$. The animals of the 3rd group are smaller in live weight at the first insemination to the 1st, 4th and 5th groups by $20 \mathrm{~kg}, 22 \mathrm{~kg}$ and $24 \mathrm{~kg}(\mathrm{P}>0.95)$, and the indicator of the 2 nd experimental group is smaller than the 4 th by $20 \mathrm{~kg}$ with a significant difference $\mathrm{P}>0.95$.

Table 1. Dynamics of change in live weight of black-and-white heifers, $\mathrm{kg}$

\begin{tabular}{|c|c|c|c|c|c|c|c|c|c|c|}
\hline \multirow{3}{*}{ Age, months } & \multicolumn{10}{|c|}{ Group } \\
\hline & \multicolumn{2}{|c|}{1} & \multicolumn{2}{|c|}{2} & \multicolumn{2}{|l|}{3} & \multicolumn{2}{|c|}{4} & \multicolumn{2}{|c|}{5} \\
\hline & $\overline{\mathrm{X}} \pm \mathrm{m}$ & $\mathrm{C}_{\mathrm{v}}$ & $\overline{\mathrm{X}} \pm \mathrm{m}$ & $\mathrm{C}_{\mathrm{v}}$ & $\overline{\mathrm{X}} \pm \mathrm{m}$ & $\mathrm{C}_{\mathrm{v}}$ & $\overline{\mathrm{X}} \pm \mathrm{m}$ & $\mathrm{C}_{\mathrm{v}}$ & $\overline{\mathrm{X}} \pm \mathrm{m}$ & $\mathrm{C}_{\mathrm{v}}$ \\
\hline At birth & $\begin{array}{c}36.2 \pm \\
0.7\end{array}$ & $\begin{array}{c}12 . \\
5\end{array}$ & $37 \pm 1.9$ & $\begin{array}{c}14 . \\
7\end{array}$ & $37 \pm 1.2$ & $\begin{array}{c}12 . \\
5\end{array}$ & $38 \pm 0.9$ & 11.5 & $37 \pm 0.9$ & 13.8 \\
\hline 6 & $\begin{array}{c}182 \pm 2 \\
.5^{*}\end{array}$ & 8.7 & $\frac{185 \pm}{3.8}$ & 5.8 & $\begin{array}{c}175 \pm 3 \\
1\end{array}$ & 6.7 & $181 \pm 0.3$ & 0.1 & $\begin{array}{c}189 \pm 2 . \\
4 \\
* * *\end{array}$ & 6.5 \\
\hline 10 & $\begin{array}{c}280 \pm 4 \\
.9 \\
\end{array}$ & 9.3 & $\begin{array}{c}277 \pm 6 . \\
8\end{array}$ & 6.9 & $\begin{array}{c}267 \pm 5 \\
8 \\
\end{array}$ & 8.2 & $273 \pm 0.4$ & 0.7 & $\begin{array}{c}290 \pm 4 . \\
4 * * *\end{array}$ & 7.8 \\
\hline 12 & $\begin{array}{c}330 \pm 5 \\
.5 *\end{array}$ & $\begin{array}{c}10 . \\
6\end{array}$ & $\begin{array}{c}323 \pm 9 . \\
2\end{array}$ & 8.1 & $\begin{array}{c}311 \pm \\
6.8\end{array}$ & 8.2 & $320 \pm 1.5$ & 2.1 & $\begin{array}{c}337 \pm 5 \\
4 * *\end{array}$ & 8.3 \\
\hline 18 & $\begin{array}{c}432 \pm \\
4.6^{*}\end{array}$ & 6.8 & $\begin{array}{c}412 \pm 8 . \\
6\end{array}$ & 5.9 & $\begin{array}{c}422 \pm 5 \\
9\end{array}$ & 5.2 & $\begin{array}{c}437 \pm 1 . \\
9 * *\end{array}$ & 1.9 & $\begin{array}{c}443 \pm 5 \\
2 * *\end{array}$ & 6.2 \\
\hline $\begin{array}{l}\text { At the first } \\
\text { productive } \\
\text { insemination }\end{array}$ & $\begin{array}{c}401 \pm 3 \\
.2 *\end{array}$ & 5.1 & $\begin{array}{c}385 \pm 9 . \\
0\end{array}$ & 6.7 & $\begin{array}{c}381 \pm 9 \\
3\end{array}$ & 9.1 & $\begin{array}{c}405 \pm 2.2 \\
*\end{array}$ & 2.4 & $\begin{array}{c}403 \pm 3 \\
6^{*}\end{array}$ & 4.7 \\
\hline
\end{tabular}

Table 2 presents the indicators characterizing the dynamics of the average daily gains of animals.

Table 2. Average daily gains, g

\begin{tabular}{|c|c|c|c|c|c|}
\hline \multirow{2}{*}{$\begin{array}{c}\text { Age, } \\
\text { months }\end{array}$} & \multicolumn{5}{|c|}{ Group } \\
\hline & 1 & 2 & 3 & 4 & 5 \\
\hline 6 & $807.2 \pm 16.92$ & $820.1 \pm 31.18$ & $768.3 \pm 20.07$ & $793.9 \pm 24.36$ & $841.6 \pm 12.81 * *$ \\
\hline 10 & $816.9 \pm 13.83 *, * *$ & $772.9 \pm 37.00$ & $764.3 \pm 16.43$ & $769.2 \pm 16.12$ & $840.1 \pm 14.82 * *$ \\
\hline 12 & $\begin{array}{c}845.0 \pm 12.33 * * \\
* * *\end{array}$ & $766.7 \pm 22.82$ & $732.1 \pm 11.26$ & $788.3 \pm 14.22$ & $788.9 \pm 11.72$ \\
\hline 18 & $563.2 \pm 26.01$ & $492.4 \pm 51.37$ & $616.7 \pm 28.33 *$ & $650.3 \pm 52.07 *$ & $589.7 \pm \pm 27.24$ \\
\hline
\end{tabular}

Table 2 shows that the greatest average daily gain at the age of 6 months have the animals of the 5th experimental group related to the 3rd group, the difference is $73.3 \mathrm{~g}$ (9.1\%), P $>0.99$. According to the gain at the age of 10 months, first-calf heifers of the control group predominate over 3rd and 4th experimental groups - $52.6 \mathrm{~g}(6.4 \%)$ with $\mathrm{P}>0.99$ and $47.7 \mathrm{~g}(5.8 \%)$ with $\mathrm{P}>0.95$, as well as cows of the 5 th group by $75.8 \mathrm{~g}(9.2 \%)$ and $70.9 \mathrm{~g}(8.6 \%)$ with $\mathrm{P}>0.99$.

At 12 months, the control group has the highest gains related to the $2 \mathrm{nd}$, 3rd, 4th and 5th experimental groups, the difference is $78.3 \mathrm{~g}(9.3 \%)$ with $\mathrm{P}>0.99,112.9 \mathrm{~g}(13.4 \%)$ with 
$\mathrm{P}>0.999,56.7 \mathrm{~g}(6.7 \%)$ with $\mathrm{P}>0.99$ and $56.1 \mathrm{~g}(6.6 \%)$ with $\mathrm{P}>0.999$. According to the average daily gain at the age of 18 months, first-calf heifers of the 3rd and 4th experimental groups prevail over 2nd group - $124.3 \mathrm{~g}(22.1 \%)$ and $157.3 \mathrm{~g}(28.1 \%)$ with a significant difference $\mathrm{P}>0.95$.

Generally, it should be noted that the animals had rather high gains, which indicates that the animals were well fed and maintained. The absolute gains are shown in Table 3.

The first-calf heifers of the 5 th experimental group have the greatest absolute gains over the 3rd group in 6 months, the difference is $13.2 \mathrm{~kg}(9.1 \%)$ with $\mathrm{P}>0.99$. The animals retained their superiority over the 3rd and 4th groups for the next 4 months, the difference was $9.1 \mathrm{~kg}(9.3 \%)$ and $8.8 \mathrm{~kg}(8.7 \%)$ with $\mathrm{P}>0.95$. The first-calf heifers of the control group at the age of 10-12 months prevailed over the peers of the 3rd experimental group - $6.8 \mathrm{~kg}$ $(13.4 \%)$ with a significant difference $\mathrm{P}>0.95$. The cows of the $3 \mathrm{rd}$, 4 th and 5 th experimental groups had the greatest gains at the age of 12-18 months, the superiority over first-calf heifers of the 2nd group is $22.4 \mathrm{~kg}(22.1 \%), 28.8 \mathrm{~kg}(28.1 \%)$ and $17.6 \mathrm{~kg}$ (17.3\%) with $\mathrm{P}>0.95$. The animals of the 5 th experimental group have the highest absolute gain in 18 months, the difference with the peers of the 2 nd and 3 rd groups are $30.8 \mathrm{~kg}(7.8 \%)$ with a significant difference $\mathrm{P}>0.99$ and $20.9 \mathrm{~kg}(5.3 \%)$ with $\mathrm{P}>0.95$.

Table 3. Absolute gains, $\mathrm{kg}$

\begin{tabular}{|c|c|c|c|c|c|}
\hline \multirow{2}{*}{$\begin{array}{c}\text { Age, } \\
\text { months }\end{array}$} & \multicolumn{5}{|c|}{ Group } \\
\cline { 2 - 6 } & $\mathbf{1}$ & $\mathbf{2}$ & $\mathbf{3}$ & $\mathbf{4}$ & $\mathbf{5}$ \\
\hline $0-6$ & $145.3 \pm 3.05$ & $147.6 \pm 3.74$ & $138.3 \pm 3.61$ & $142.9 \pm 4.38$ & $151.5 \pm 2.31 * *$ \\
\hline $6-10$ & $98.0 \pm 2.49$ & $92.8 \pm 4.44$ & $91.7 \pm 2.96$ & $92.3 \pm 2.90$ & $100.8 \pm 2.67 *$ \\
\hline $10-12$ & $50.7 \pm 2.22 *$ & $46.0 \pm 2.74$ & $43.9 \pm 2.03$ & $47.3 \pm 2.56$ & $47.3 \pm 2.11$ \\
\hline $12-18$ & $101.4 \pm 6.68$ & $88.6 \pm 6.16$ & $111.0 \pm 5.10^{*}$ & $117.1 \pm 9.37 *$ & $106.2 \pm 4.90^{*}$ \\
\hline $0-18$ & $395.4 \pm 5.96$ & $375.0 \pm 9.41$ & $384.9 \pm 6.12$ & $399.6 \pm 9.64$ & $405.8 \pm 5.30^{*} * *$ \\
\hline
\end{tabular}

Table 4 shows that the control group has the highest relative gain in 6 months (133.4\%), as well as over the next 4 months $-42.5 \%$. The difference in the period from 0-6 months between the first group with the rest of the experimental groups is $0.1-2.9 \%$, and from 10 12 months - $0.3-2.3 \%$. According to the relative gains at the age of $10-12$ months, groups $1,2,4$ and 5 have superiority over their peers of the 3rd group $-4.7 \%(\mathrm{P}>0.999), 3.4 \%$ $(\mathrm{P}>0.99), 4 \%(\mathrm{P}>0.999)$ and $3.2 \%(\mathrm{P}>0.99)$ accordingly.

Table 4. Relative gains, \%

\begin{tabular}{|c|c|c|c|c|c|}
\hline \multirow{2}{*}{$\begin{array}{c}\text { Age, } \\
\text { months }\end{array}$} & \multicolumn{5}{|c|}{ Group } \\
\cline { 2 - 6 } & $\mathbf{1}$ & $\mathbf{2}$ & $\mathbf{3}$ & $\mathbf{4}$ & $\mathbf{5}$ \\
\hline $0-6$ & $133.5 \pm 1.46$ & $133.3 \pm 2.76$ & $130.5 \pm \pm 2.39$ & $131.1 \pm 2.01$ & $133.3 \pm 1.47$ \\
\hline $6-10$ & $42.5 \pm 0.73$ & $40.2 \pm 1.47$ & $41.5 \pm \pm 0.63$ & $40.7 \pm \pm 0.73$ & $42.2 \pm 0.75$ \\
\hline $10-12$ & $16.6 \pm 0.54 * * *$ & $15.3 \pm 0.59 * *$ & $11.9 \pm 0.73$ & $15.9 \pm \pm 0.74 * * *$ & $15.1 \pm 0.59 * *$ \\
\hline $0-18$ & $26.6 \pm 1.39$ & $24.1 \pm 1.85$ & $30.3 \pm 1.54 *$ & $30.9 \pm 2.27 *$ & $27.2 \pm 1.29$ \\
\hline
\end{tabular}

At the age of 12-18 months, animals of the 3rd and 4th groups have the highest gain related to the first-calf heifers of the 2nd group - 6.2 and $6.8 \%$, with a significant difference $\mathrm{P}>0.95$. For the whole growing period (18 months), the control group has superiority over the experimental group (181\%). 
Many scientists believe that the highest milk production has well-developed, but not the largest animals. Each breed has its own standard. Table 5 shows body measurements of the black-and-white first-calf heifers.

Table 5. First-calf heifer body measurements, $\mathrm{cm}$

\begin{tabular}{|c|c|c|c|c|c|c|}
\hline & \multicolumn{5}{|c|}{ Group } \\
\hline & & 1 & 2 & 3 & 4 & 5 \\
\hline & & \multicolumn{5}{|c|}{$\overline{\mathrm{X}} \pm \mathrm{m}$} \\
\hline \multirow{7}{*}{ 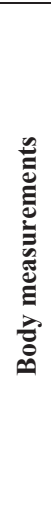 } & WH & $\begin{array}{c}139.9 \pm \\
0.21 * *, * * *\end{array}$ & $\begin{array}{c}137.5 \pm \\
0.24 * * *\end{array}$ & $\begin{array}{c}136.1 \pm \\
0.21\end{array}$ & $\begin{array}{c}139.0 \pm \\
0.24 * * *\end{array}$ & $\begin{array}{c}137.7 \pm \\
0.27 * * *\end{array}$ \\
\hline & $\mathrm{CW}$ & $\begin{array}{c}46.1 \pm \\
0.29^{* * *}\end{array}$ & $\begin{array}{c}44.0 \pm \\
0.24^{* *, * * *}\end{array}$ & $\begin{array}{c}43.0 \pm \\
0.18^{* * * *}\end{array}$ & $\begin{array}{c}41.5 \pm \\
0.24\end{array}$ & $\begin{array}{c}47.9 \pm \\
1.18^{* *, * * *}\end{array}$ \\
\hline & $\mathrm{CD}$ & $\begin{array}{c}68.7 \pm \\
1.09 \\
\end{array}$ & $\begin{array}{c}69.9 \pm \\
0.19^{*, * * *}\end{array}$ & $\begin{array}{c}69.1 \pm \\
0.21 * *\end{array}$ & $\begin{array}{c}68.0 \pm \\
0.24\end{array}$ & $\begin{array}{c}70.3 \pm \\
1.19 \\
\end{array}$ \\
\hline & HG & $191.6 \pm 0.84$ & $191.0 \pm 0.24$ & $\begin{array}{c}192.8 \pm 0.28 \\
*, * *, * * *\end{array}$ & $\begin{array}{c}192.0 \pm 0.24 \\
* *\end{array}$ & $191.0 \pm 0.47$ \\
\hline & $\mathrm{BL}$ & $\begin{array}{c}160.8 \pm \\
0.28^{*}\end{array}$ & $\begin{array}{c}163.5 \pm \\
0.24 * * *\end{array}$ & $\begin{array}{c}160.1 \pm \\
0.21\end{array}$ & $\begin{array}{c}161.5 \pm \pm \\
0.24 * * *\end{array}$ & $160.3 \pm 1.96$ \\
\hline & RW & $\begin{array}{c}51.8 \pm \\
0.62 * *\end{array}$ & $\begin{array}{c}50.0 \pm \\
0.24\end{array}$ & $\begin{array}{c}50.6 \pm \\
0.37\end{array}$ & $\begin{array}{c}51.5 \pm \\
0.24 * * * *\end{array}$ & $\begin{array}{c}50.0 \pm \\
1.25 \\
\end{array}$ \\
\hline & $\mathrm{CC}$ & $\begin{array}{c}19.1 \pm \\
0.04^{* *, * * *}\end{array}$ & $\begin{array}{c}18.2 \pm \\
0.12\end{array}$ & $\begin{array}{c}18.7 \pm \\
0.23\end{array}$ & $\begin{array}{c}18.4 \pm \\
0.17\end{array}$ & $\begin{array}{c}18.6 \pm \\
0.19\end{array}$ \\
\hline
\end{tabular}

Note: WH - withers height, CW - chest width, CD - chest depth, HG - heart girth, BL - body length, RW rump width, $\mathrm{CC}$ - cannon bone circumference.

According to the WH among the studied groups, the first control group prevails over the peers of the second, fourth and fifth groups, the difference is $2.4 \mathrm{~cm}(1.7 \%)$ with $\mathrm{P}>0.999$, $0.9 \mathrm{~cm}(0.6 \%)$ with $\mathrm{P}>0.99$ and $2.2 \mathrm{~cm}(1.6 \%)$ with $\mathrm{P}>0.999$; the second group prevails over the first-calf heifers of the third group $-1.4 \mathrm{~cm}(1.01 \%)$ with a significant difference $\mathrm{P}>0.999$; the fourth group prevails over the animals of the second, third and fifth groups $1.5 \mathrm{~cm}(1.1 \%), 2.9 \mathrm{~cm}(2.1 \%)$ and $1.3 \mathrm{~cm} \mathrm{(1 \% )} \mathrm{with} \mathrm{P}>0.999$; as well as the fifth group over the cows of the third group $-1.6 \mathrm{~cm}(1.1 \%)$ with a significant difference $\mathrm{P}>0.999$.

The largest CW has the animals of the first and fifth groups related to the second, third and fourth groups, the difference is $2.1 \mathrm{~cm}(4.6 \%), 3.1 \mathrm{~cm}(6.7 \%), 4.6 \mathrm{~cm}(10 \%)$ with $\mathrm{P}>0.999$ and $3.9 \mathrm{~cm}(8.5 \%)$ with $\mathrm{P}>0.99,4.9 \mathrm{~cm}(10.6 \%), 6.4 \mathrm{~cm}(13.9 \%)$ with $\mathrm{P}>0.999$; the second group related to the third and fourth groups $-1 \mathrm{~cm}(2.2 \%)$ with $\mathrm{P}>0.99$ and 2.5 $\mathrm{cm}(5.5 \%)$ with $\mathrm{P}>0.999$; the third group related to the fourth group $-1.5 \mathrm{~cm}(3.3 \%)$ with $\mathrm{P}>0.999$.

According to the chest depth, the difference between the second group with peers of the third and fourth groups is $0.8 \mathrm{~cm}(1.1 \%)$ with a significant difference $\mathrm{P}>0.95$ and $1.9 \mathrm{~cm}$ (2.7\%) with $\mathrm{P}>0.999$, and first-calf heifers of the third group prevail the animals of the fourth group by $1.1 \mathrm{~cm}(1.6 \%)$ with a significant difference $\mathrm{P}>0.99$. The highest $\mathrm{HG}$ indicator has the first-calf heifers of the third group related to the second, fourth and fifth groups $-1.8 \mathrm{~cm}(0.9 \%)$ with $\mathrm{P}>0.999,0.8 \mathrm{~cm}(0.4 \%)$ with $\mathrm{P}>0.95$ and $1.8 \mathrm{~cm}(0.9 \%)$ with a significant difference $\mathrm{P}>0.99$; as well as the fourth group related to the second group $-1 \mathrm{~cm}$ $(0.5 \%)$ with $\mathrm{P}>0.99$. According to the $\mathrm{BL}$ the difference between the second group with the first, third and fourth groups is $2.7 \mathrm{~cm}(1.7 \%), 3.4 \mathrm{~cm}(3.8 \%)$ and $2 \mathrm{~cm}(1.3 \%)$ with $\mathrm{P}>0.999$; fourth and third groups $-1.4 \mathrm{~cm}(0.8 \%)$ with $\mathrm{P}>0.999$; the first and third groups $0.7 \mathrm{~cm}(0.4 \%)$ with a significant difference $\mathrm{P}>0.95$. According to the RW the animals of the first group prevail over their peers of the second group $-1.8 \mathrm{~cm}(3.5 \%)$ with $\mathrm{P}>0.99$; the fourth group over the second and third groups $-1.5 \mathrm{~cm}$ (2.9) with P0.999 and $0.9 \mathrm{~cm}(1.1 \%)$ with $\mathrm{P}>0.95$. The largest $\mathrm{CC}$ have the heifers of the control group, the difference with the second, fourth and fifth groups is $0.9 \mathrm{~cm}(4.7 \%), 0.7 \mathrm{~cm}(3.7 \%)$ with $\mathrm{P}>0.999$, and $0.5 \mathrm{~cm}$ $(2.6 \%)$ with $\mathrm{P}>0.99$. 


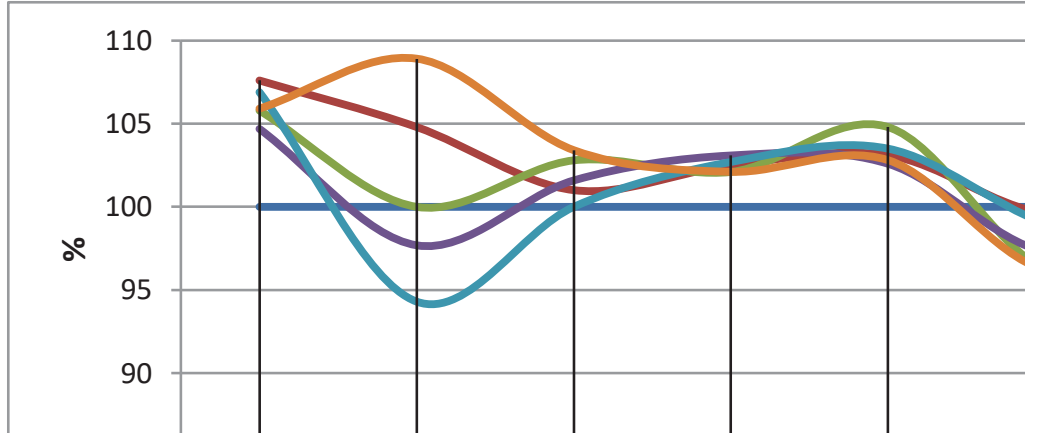

Fig. 1. Exterior profile of first-calf heifers

In addition to body build indices, body measurements are used to create exterior profiles. An exterior profile is a graphical representation of difference in measurements or body build indexes of an animal or a group of animals related to a standard or other model criteria. Fig. 1 shows the exterior profile of first-calf heifers with different combinations of selection in Plemzavod im. Lenin LLC related to the breed standard.

All cows are tall, the second group corresponds to the breed standard in chest width, while the first and fifth have wide chests, and the third and fourth groups have narrow ones. The animals have a well-developed chest, the fourth group corresponds to the standard, the bones are strong, they have a stretched constitution, the rump width does not correspond to the norm, the cannon bone circumference of the control group is close to the standard related to the to the experimental groups.

The absolute values of body measurements allow to compare the development of selected indicators of animals, but do not characterize the proportions of their body build. To judge about the type of animal constitution and the relative development of one or another, the body build indices are calculated, which characterize the ratio (in \%) of anatomically related body measurements. When determining the body type of animals with various linear combinations, we calculated the following body build indices: leggy, stretchiness, pelvis-chest, chest, blockiness and boniness were calculated, as well as the coefficient of milk production, by which the direction of the animal productivity can be judged (Table 6).

Table 6. Body build indices and the coefficient of milk production of first-calf heifers, $\%$

\begin{tabular}{|l|c|c|c|c|c|}
\hline \multirow{2}{*}{ Indices } & $\mathbf{1}$ & $\mathbf{2}$ & $\mathbf{3}$ & $\mathbf{4}$ & $\mathbf{5}$ \\
\hline Leggy & $50.9 \pm 0.82$ & $49.1 \pm \pm 0.20$ & $49.2 \pm 0.08$ & $51.1 \pm 0.09$ & $48.9 \pm 0.96$ \\
\hline Stretchiness & $114.9 \pm 0.28$ & $118.9 \pm 0.03$ & $117.6 \pm 0.03$ & $116.2 \pm 0.03$ & $116.5 \pm 1.65$ \\
\hline Pelvis-chest & $88.9 \pm 1.06$ & $88.0 \pm 0.06$ & $84.9 \pm 0.31$ & $80.6 \pm 0.09$ & $95.7 \pm 4.48$ \\
\hline Chest & $67.0 \pm 0.76$ & $62.9 \pm 0.27$ & $62.2 \pm 0.14$ & $61.0 \pm 0.14$ & $68.1 \pm 2.61$ \\
\hline Blockiness & $119.2 \pm 0.65$ & $116.8 \pm 0.02$ & $120.4 \pm 0.22$ & $118.9 \pm 0.28$ & $119.1 \pm 1.55$ \\
\hline Boniness & $13.7 \pm 0.02$ & $13.3 \pm 0.08$ & $13.7 \pm 0.15$ & $13.2 \pm 0.10$ & $13.5 \pm 0.16$ \\
\hline $\begin{array}{l}\text { Coefficient of milk } \\
\text { production }\end{array}$ & $1592 \pm 31$ & $1610 \pm 52$ & $1601 \pm 33$ & $1648 \pm 29$ & $1523 \pm 20$ \\
\hline
\end{tabular}


Table 6 shows that all groups of first-calf heifers, according to the leggy and stretchiness index, belong to the milk-meat direction of productivity, as well as according to the pelvic-chest index, however, 3rd group belongs to the meat direction of productivity, and 4th group - to the dairy direction. All groups belong to the milk production direction according to the downwardness and chest index, and to the meat one according to the boniness index.

\section{Conclusions}

Findings indicate that the highest daily average and absolute gains have the animals of the 5th experimental group (animals with the cross line affinity according to their paternal and maternal ancestors) $(\mathrm{P}>0.99)$, and according to the relative gains - the control group (pure lines).

It is proved that first-calf heifers of all studied groups are tall, the first and fifth group have wide chest, the second group corresponds to the breed standard, and the third and fourth groups have narrow chest. Each studied group of animals have well-developed chest depth, strong bones, and stretched constitution. The rump width and cannon bone circumference does not correspond to the norm.

It was identified that first-calf heifers in Plemzavod im. Lenin LLC have a high milk production coefficient, which indicates their milk type.

\section{References}

1. O. A. Basonov, V. V. Klipova, N. P. Shkilev, I. A. Elfimova, The role of sire bulls in increasing the level of realization of the genetic potential of dairy herds (2019)

2. O. A. Basonov, N. V. Vorobyova, M. E. Taigunov, S.S. Basonova, Zootechniya, 7, 14$15(2010)$

3. I. V. Malyavko, V. A. Malyavko, Zootechniya, 5, 15-17 (2016)

4. Yu. A. Svetova, T. A. Guseva, Zootechniya, 10, 17-18 (2014)

5. T.T.Tarchokov, Z.M.Aisanov , S.F. Sukhanova, Mishhozhev, A.A., Balpanov, D.S., IOP Conference Series: Earth and Environmental Science, 341(1), 012047 (2019)

6. A.A.Mishkhozhev, M.G.Tleinsheva, Z.M.Aisanov, T.T.Tarchokov, Zootechniya, 11, 24-27 (2017)

7. A.A. Zhilyaev, T.T.Tarchokov, I.G. Sudorgina, R.Z.Abdulkhalikov, M.G.Tleinsheva, D.S.Balpanov, A.A.Kogotyzhev, Zootechniya, 9, 8-11 (2020)

8. T.T. Tarchokov, Zootechniya, 5, 27-30 (1996)

9. M.O. Baytaev, Ts. B. Kagermazov, T. T.Tarchokov, Agrarnaya Russia, 1, 28-30 (2013)

10. M. B. Ulimbashev, T. T. Tarchokov, Agrarian Science, 6, 24-25 (2005)

11. T. T. Tarchokov. A. M. Tkhazeplov, J. Zootechniya, 12, 5-7 (2004)

12. A. B. Baragunov, E. A. Kushaeva, M. M. Hamokov, A. V. Sagatelian, E3S Web of Conferences, International Conference on Modern Trends in Manufacturing Technologies and Equipment, ICMTMTE 2020, 193 (2020)

13. A. B. Baragunov, I. A. Savvateeva, S. H. Kushaev, A. A. Kumakhov, Z. R. Kudaev, 2nd International Scientific Conference on Agribusiness, Environmental Engineering and Biotechnologies, AGRITECH-II 2019, IOP Conference Series: Earth and Environmental Science, 3 (2019) 
14. T. T. Tarchokov, Z. M. Aisanov, S. F. Sukhanova, M. G. Tleinsheva, A. A. Mishhozhev, D. S. Balpanov, Russian Conference on Innovations in Agricultural and Rural Development 2019, AgroCON 2019, IOP Conference Series: Earth and Environmental Science, 1 (2019) 